\title{
The Impact of Tourists' Emotional Experiences on Destination Image, Tourists' Satisfaction and Willingness to Recommend
}

\author{
THI LIEN PHAM \\ Department of Social Science, Economics and Management \\ VNU International School \\ Vietnam National University \\ Hanoi, VIETNAM \\ TAM PHAN THI THANH \\ Vietnam Japan University \\ Vietnam National University \\ Hanoi, VIETNAM \\ THI MAI LE* \\ Department of Social Science, Economics and Management \\ VNU International School \\ Vietnam National University \\ Hanoi, VIETNAM
}

\begin{abstract}
Today, globalization as well as the advancement of technology is narrowing the distances of nations. Vietnam has become an attractive destination of tourists due in part to its charm, natural beauty, as well as its rich history and culture. The aim of this research is to study the effects of emotional experience factors on tourists' satisfaction and their willingness to recommend the destinations, this study follows revised Destination Emotion Scales (DES) model. The survey was carried out with 224 foreign tourists who have travelled to a few famous places in Vietnam at least one time by both online and offline method. The methodology used in our research is a quantitative method. SPSS software 20 and AMOS 21 with SEM (structural equation modelling) were used to carry out analyzing on data gathered through a survey. This research found that the emotions of joy and love as significant influences on tourists' satisfaction and its effect on intention to recommend while exploring whether or not the emotion of positive surprise does not support this relationship. The research makes a significant contribution to tourism marketing in Vietnam because some of the empirical findings found in the study deal with aspects of tourists' satisfaction and their willingness to recommend necessary to improve tourism.
\end{abstract}

Key-Words: tourist satisfaction, tourists' emotional experiences, overall destination image, willingness to recommend.

Received: April 10, 2021. Revised: October 22, 2021. Accepted: November 5, 2021. Published: November $22,2021$.

\section{Introduction}

According to the report "Travel \& Tourism Economic impact 2018, South East Asia" issued by The World Travel \& Tourism Council (WTTC, 2018), the contribution of tourism in GDP in 2017 is 329.5 billion USD and accounts for $12 \%$ of the total grand GDP and is estimated to continue to increase up to 598.3 billion USD in 2028 (estimated for $13 \%$ of total GDP) (WTTC, 2018). This rate points out the important role of tourism in economic development currently. Therefore, South East Asia would be well served to develop tourism as an economic incentive. Moreover, the impact of globalization and economic trends towards emergent Southeast Asia economies currently increased tourism demand in this area dramatically, thus bringing big potential in economic development. In 2017, Asia and Pacific accounts for 
$30 \%$ of world international tourism receipts (UNWTO, 2017). Following these trends, Vietnam is also becoming an attractive destination for tourists. In 2017, Vietnam welcomed 12.9 million international tourists, which offered a gain of 541 billion VND of income and directly contributed $7.9 \%$ of GDP [1].

To boost tourism development, the Vietnamese government has launched many activities such as issuing tourism legal documents, organized events, and festivals, improving public transportation and tourism facilities. Also, tourism research has recently developed tourism reports which are published frequently and provide statistics. Through the awareness of the important role of marketing in tourism, tourism marketing strategies are also focused on promoting Vietnam as a destination image to the world through advertising actives, exhibitions, and international cooperation. Tourist marketing researchers trying to find better solutions for Vietnam marketing tourism are concentrated on 1) evaluating the tourist satisfaction at destinations [2]; 2) the impact of destination on loyalty [3]; and 3) tourism service quality to behaviour intention [4]. However, there are only a few journal articles that mention tourists' emotional experiences within Vietnam tourism marketing market.

From a tourist marketing perspective, the role of tourists' emotional responses has been acknowledged as a useful factor when applied to tourism marketing strategies. Therefore, some countries are using emotional tourism slogans to attract more tourists because they think that emotions will impact tourist's expectation on vacation destination [5]. For example, India "Incredible India", Thailand "Amazing Thailand", Indonesia "Wonderful Indonesia", the Philippines "It is more fun in Philippines", Brazil "Sensational Brazil" [5]. Nevertheless, studying tourists' emotions are problematic because human emotions are complicated and difficult to measure. Especially the study of tourists' emotional experiences of overall image, satisfaction, and willingness to recommend is more complicated because there is no official standardization to measure the level of emotional effect of all these factors and the linkage between them are under study. It was discovered that positive emotions have an effect on the overall image, satisfaction, and both effect intention to recommend [6]. These results and their Destination Emotion Scales (DES) conceptual modes are quite recent and more research using this theoretical model is warranted. This study will be utilizing the revised DES model, a model that has as yet only been used a few times [7].

The aim of this research is to study the effects of emotional experience factors on tourists' satisfaction and their willingness to recommend the destinations to others. In detail, to research correlations among emotional experiences, overall image, satisfaction, and willingness to recommend. Therefore, outcomes of this project have the potential to raise awareness of the role of tourists' emotional experiences in tourism marketing management. That may contribute to practical evidence for further tourism market research.

\section{Literature Review}

The structure of the proposed framework is shown in Figure 1. In total nine (9) hypotheses are drawn from six constructs, namely, joy, love, positive surprise, overall destination image, tourist satisfaction and willingness to recommend.

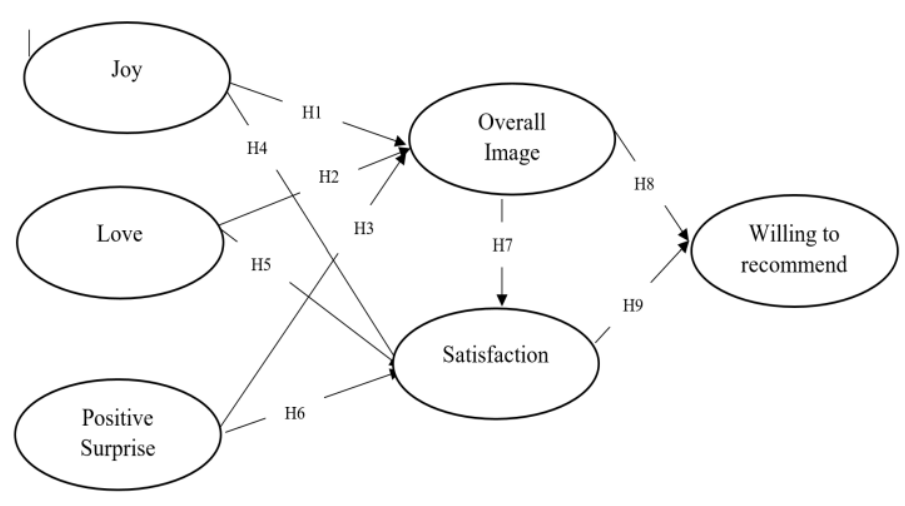

Fig. 1: Proposed research framework

First, the conceptual framework of this study based on DES dimensions developed by Hosany and Gilbert [8]. The authors conducted the research aimed to provide the theoretical ground and conceptual model to measure tourists' emotional experiences. Based on the past theoretical backgrounds, the authors contributed to developing a Destination Emotion Scales (DES) conceptual model with 15-items, three-dimensional confirmatory factor (Joy, Love, and Positive Surprise). After that, the researchers analyze the relationship between emotional experiences, satisfaction, and intention to recommend. According to the research results, the authors supposed that tourists' emotional experiences have significant effects on behavioral intentions through satisfaction. 
Second, the study applied DES dimension because of the usefulness in measuring the tourists' emotional experiences toward destinations. In addition, the scale's validity of DES was tested with the appropriated results [9].

Finally, the relationship of tourists' emotional experiences among satisfaction and behavioral intentions are under investigation due to the gaps of the impact of various factors surrounding this relationship such as overall image, negative affections, and different contexts. According to the study of Hosany and Prayag [6], this research is the expending DES model development, the authors added the negative emotion factor ("Unpleasantness") to balance the measurement dimension scales of emotion. Furthermore, the authors wanted to examine the relationship between tourists' emotional experiences and satisfaction in order to understand behavior intention.

Recently, some research based on DES dimensions conducted to explore tourist behavior in Petra - the south of Amman (the capital of Jordan), Sardinia - Italy, India [7]. As the results, the positive emotions are important antecedents of the overall image, satisfaction, and behavior attention; there is a strong connection between overall image and satisfaction; both overall image and satisfaction contributed to intention behaviors (Recommend or revisit).

\subsection{Tourists' Emotional Experiences}

Emotions are affective states characterized by episodes of intense feelings associated with a specific referent and instigate specific response behaviors. According to the previous literature, there are two major theoretical approaches to study emotions. They are dimensional (valence based) and categorical (emotion specificity). To explain for the relationship of human emotions, Plutchik [10] illustrated emotions by Wheel of Emotions. The wheel includes two dimensions are polarity and intensity. Polarity indicates which emotion is either positive or negative. Next, intensity shows which degree of positive and negative emotion. There are sixteen emotions including eight basic emotions and eight advanced emotions, with two basic emotions in each. The mixture of two emotions into the circular pattern creates new emotions. For examples, the mixture of joy and acceptance creates loves; the combination of joy and surprise creates delight. This study selected joy, love and positive surprise are the main items of emotional experiences for the following reasons:
Joy plays an important role in tourists' emotional experiences [8]. Joy is often associated with positive outcomes in tourism such as loyal with using a service or satisfy in choosing a destination. In addition, the joy dimension includes emotions of cheerfulness, pleasure, and playfulness. Those emotional experiences are high expectation seeking of tourists while they are on their holidays. Thus, joy is a key factor in studying emotional experiences in order to satisfy the tourists.

Past studies of love dimension consist of tenderness, caring, and affection which effect on the consumers' emotions. The feeling of love was found in some studies tourism researches related to branding strategies and destination marketing. The study of Whang, Allen [11] is the first to capture consumer's love toward a product when she conducted the research to measure the love to her bike and motorcycles with three variables: eros (passionate love), mania (possessive love), and agape (altruistic love).

Carroll and Ahuvia [12] define love for a brand as "the degree of passionate emotional attachment that a person has for a particular trade name." Consumers' love, hence, includes the following characteristics: (1) passion for a brand, (2) brand attachment, (3) positive evaluation of the brand, (4) positive emotions in response to the brand, and (5) declarations of love toward the brand. These studies help better understand the construct of love in a consumer behavior context but yet have some theoretical, methodological, and managerial limitations.

Love was examined in the differing context of tourism such as love for the tourism industry [13], love for a destination [14, 15], and love for an airline organization [16]. Previous studies discovered that there is a connection between brand loyalty and positive word of mouth. Therefore, love plays an importation role of emotion influencing to recommendation behaviors.

Izard [17] supposed that surprise is not the same sense as joy or sadness. Even it does not consist of all the characteristics of the other emotions, but it has some useful functions. The surprise is activated by a sharp increase in neural stimulation caused by any sudden and unexpected event. In the moment of surprise, your mind seems to be blank and hard to react. There are two types of surprise: positive surprise goes with other emotion such as happiness, joy, and pleasure; negative surprise often goes with emotions such as anger, fear, and distress. The 
surprise is not like other emotions because it does not motivate behavior for a long time. Thus, studying on surprise to help prepare for the individual to deal effectively with the new or sudden event and with the consequences of this event. Moreover, studying on surprise to find out the important function of surprise is to clear the nervous system of ongoing activity that would interfere with adjustment to a sudden change in our environment.

Lindgreen and Vanhamme [18] argued that surprise has effects on marketing variables such as customer satisfaction, customer retention, and trust. Positive surprise draws attention, promote positive attitudes toward the advertising, and stimulate word of mouth [19]. That paper provided the guidance for retailer to design surprise that improve consumer attitudes and profitability. Prayag, Hosany [20] found that positive surprise has positively influence tourists' satisfaction.

In the tourism industry, emotions act as a significant component of tourist experiences. Tourist emotional experiences with the same valence but have different influences on outcome variables such as judgment [21]; The destination decision making [22]; Satisfaction [22, 23]; Behavior intention [24-27].

\subsection{The Relationship Between Emotional Experiences On Overall Image and Satisfaction}

Tourism, unlike other business operations, is a business that sells unforgettable experiences [28]. Tourist satisfaction plays an important role as the core indicator for marketing in travel and hospitality business. Thus, there are increasing the number of studies investing aspects of customer satisfaction in tourism, travel, and hospitality. Prayag, Hosany [20] pointed out that satisfaction is the key outcome of tourists' emotional responses such as joy, love, positive surprise and unpleasantness.

There is a number of researches on the role of emotion in the relationship between satisfaction or overall image in different tourism context and destination [7, 29-31]. Prior studies of Hosany, Prayag [9] examined the suitability of DES in different destinations such as a country (Thailand) and a heritage site (Petra) aimed to prove that DES is a useful tool to measure tourists 'emotional experiences on destination image. The results of using DES to measure those relationships are normally the same indifferent contexts. For examples, the relationship of all emotional experiences (joy, love, positive surprise) on tourist satisfaction in the context of India yoga destination
(Rishikesh) are supportive [7]. Moreover, the emotional items (joy, love, and positive surprise) and satisfaction are supportive in the case of a UNESCO world heritage site (Petra) [6]. In the context of Thailand, positive emotion and satisfaction are significant determinants of place attachment [32]. However, the recent study of Prayag, Hosany [33] on the island of Sardinia, Mediterranean Sea discovered that emotional experiences have different support to the relationship with overall image and satisfaction. For example, the relationship of overall image and joy, love are supportive while overall image and positive surprise are not supportive. Beside, joy and love have no significate effect on satisfaction. Although, the relationship between positive surprise and satisfaction is a positive support. Base on the contextual information of previous studies, there is a gap in studying the relationship among emotional experiences on the overall image, satisfaction. Therefore, the study continues to discover the relationships in the Vietnam context in order to provide further empirical evidence of the relationship.

\section{Group 1: Joy, Love, Positive Surprise On Overall Image}

There are several theoretical studies on the relationship between emotions and overall images such as positive emotions toward the natural environment [34], holistic destination image and emotional attributes [35], and nostalgic emotions toward to restaurant image [36]. Recently, the scholars emphasize on emotional empirical research, for example, the empirical study in unique historical environment and culture destination [33]; in the wellness area of yoga in India [7]. However, investigating the relationship between positive overall image is new and scare, thus demanding for further examination. Based on this literature, hypotheses are established as follows:

H1: The emotion of Joy has a positive influence on the overall image.

H2: The emotion of Love has a positive influence on the overall image

H3: The emotion of Positive Surprise has a positive influence on the overall image.

\section{Group 2: Joy, Love, Positive Surprise On Satisfaction}

In tourism marketing research, tourist satisfaction is the most popular research topic of scholars. Recently, the relationship between emotion and satisfaction is an emerging topic attracted to 
scholars such as satisfaction is influenced favorably by the emotion of joy [37], or emotion of not only happiness but also excitement and pleasure [38]. In the series of studying in positive emotions and satisfaction, Hosany and Praya et al often examine this relationship in different contexts such as heritage destination with domestic tourists $[6,33]$; Thailand context with international tourists [32]. However, to understand more about this relationship is new and required to further testing. According to the background, the study hypotheses were constructed:

H4: The emotion of Joy is positively influence on tourist satisfaction with a destination.

H5: The emotion of Love is positively influence on tourist satisfaction with a destination.

H6: The emotion of Positive surprise is positively influence on satisfaction with a destination.

\subsection{The Relationship Between Satisfaction and Overall Images and Behavioral Intentions}

Chen and Tsai [39] indicated that the impact of destination image on behavioral intentions in both directly and indirectly. The research also pointed out the linkage path destination image $\rightarrow$ trip quality $\rightarrow$ perceived value $\rightarrow$ satisfaction $\rightarrow$ behavioral intentions.

Previous research showed out that destination image has an influence on tourist behaviors [31, 40, 41]. Tourist consumption process is divided into three stages: before a visit, during a visit, and post a visit [42]. During tourist consumption process, destination image plays three important roles in behaviors: 1) to influence the destination choice decision-making process; 2) to evaluate (satisfy) the service quality during onsite and experience; 3 ) to intend the future behavioral intentions (intention to revisit and willingness to recommend).

It is recognized that satisfaction affects destination selection decisions, consumption of goods and service at a destination, and behavior intention. It is double that consumers are satisfied with the product/service; they are more likely to continue to purchase. Related research indicates that satisfaction is a function of expectations and overall performance. After comparing the expectations with perceived performance of the destination, destination satisfaction can be considered [42]. In this context, satisfaction resulting from a destination can be better understood by evaluation and perception of tourists regarding a tourism destination.
Meng, Tepanon [43] stated that tourist satisfaction of a destination is a function of attribute importance, performance, and tourist motivation. The major question raised in this research is that to what extent the visitors' evaluation of destination attributes (the importance and performance factors) and tourist motivation relate to their overall satisfaction.

\section{Group 3: Overall Images, Satisfaction On Willingness to Recommend}

Wang, Tran [44] indicated that overall image impacted directly on tourist satisfaction, and thereby influenced the revisit intention or positive word of mouth recommendations. Although most of the studies confirm that overall image has significant effects on behavioral recommendations through satisfaction, the overall image in the context of positive emotions impacted on tourists' satisfaction and the willingness to recommend is recently mentioned [33].

The relationship between tourist satisfaction and behavior intentions is well documented in some research [41, 45, 46]. Satisfied tourists are more likely to revisit and recommend the destination to others [39, 47, 48]. Based on this literature, hypotheses are established as follows:

H7: Overall image is positively associated on tourist satisfaction with a destination.

H8: Overall image is positively associated on recommend the destination.

H9: Tourist satisfaction is positively associated on recommend the destination

\section{Research Methodology}

\subsection{Sample and Data Collection}

Data used in this research were obtained from structured questionnaires to target respondents who were foreign tourists who have travelled to a few famous places in Vietnam at least once time.

According to the standard of testing variables by [49] the sample size to be collected should be no less than five times of the watched variables. In this research, the quantity of watched variables in exploration model is 24 . Therefore, the sample size needs at least $24 \times 5=120$ responses.

Prior to formal data collection, a pilot test was conducted by collecting the comments of 12 interviewees with the draft of survey questionnaires aiming to adjust errors in survey questionnaires before disseminating them officially. 
Responses were collected through online and offline channel. One hundred paper survey questionnaires were sent out to tour guides of a travel agency (Vietindo Travel) and 30 hard copies were handled to freelance tour guides. Online questionnaires were posted to social network pages such as: Hanoi Massive Community; Sai Gon Expats; Vietnam Massive - a new era; Expats \& Locals in Saigon; Love in Hanoi

In this study, a total of 246 responses were obtained from both channels, in which, 12 responses were rejected in online form due to wrong target candidates and careless answers, remaining 224 usable responses were considered appropriate for analysis, which much higher than recommended value.

From descriptive statistics shown in Table 1, a majority of respondents were Asia (74.4\%), 14.7\% in Europe, $0.4 \%$ in America, and $4 \%$ in Australia. Males account for $37.5 \%$ and female accounts for $62.5 \%$. The age group of participants were catalogued as follows: $16-24$ years old $(10,3 \%) ; 25-$ 34 (46.9\%); 35-44 (25.4\%); 45-54 (12.9\%); 55-64 (4\%); and more than $64(0.4 \%)$. In term of religion, most of respondents follow "no religion" accounted for $57.6 \%, 22.8 \%$ Christianity, $12.9 \%$ Buddhism, $2.2 \%$ Hinduism, $0.4 \%$ Islam; $4 \%$ other religion. Most of the respondents were well educated, with the haft of them completed college degrees $(47.8 \%)$ or postgraduate degrees $(45.5 \%)$. Thus, all most participants have average income: 10,001-20,000 $(30.8 \%) ; 20,001-30,000(23.7 \%)$; and more than $30,000(26.8 \%)$.

Table 1. Sample Characteristics $(n=224)$

\begin{tabular}{|l|l|c|r|}
\hline \multirow{2}{*}{$\begin{array}{l}\text { Demogra } \\
\text { phic }\end{array}$} & \multirow{2}{*}{$\begin{array}{c}\text { Classificatio } \\
\mathbf{n}\end{array}$} & \multicolumn{2}{|c|}{$\begin{array}{c}\text { Proportion (sample, } \\
\text { n=224) }\end{array}$} \\
\cline { 2 - 4 } Nation & Asia & 167 & N \\
& Europe & 33 & 74.6 \\
& African & 1 & 14.7 \\
& America & 14 & 0.4 \\
& Australia & 9 & 6.3 \\
& Female & 140 & 4.0 \\
\hline Gender & Male & 84 & 62.5 \\
& From 16-24 & 23 & 37.5 \\
\hline Age & $25-34$ & 105 & 10.3 \\
& $35-44$ & 57 & 46.9 \\
& $45-54$ & 29 & 25.4 \\
& $55-64$ & 9 & 12.9 \\
& More than 64 & 1 & 4.0 \\
& & & 0.4 \\
\hline
\end{tabular}

\begin{tabular}{|c|c|c|c|}
\hline Religion & $\begin{array}{l}\text { Buddhism } \\
\text { Christianity } \\
\text { Hinduism } \\
\text { Islam } \\
\text { No religion } \\
\text { Other }\end{array}$ & $\begin{array}{c}29 \\
51 \\
5 \\
1 \\
129 \\
9\end{array}$ & $\begin{array}{r}12.9 \\
22.8 \\
2.2 \\
0.4 \\
57.6 \\
4.0\end{array}$ \\
\hline Income & $\begin{array}{l}\text { Less than } \\
5,000 \\
5,001-10,000 \\
10,001- \\
20,000 \\
20,001- \\
30,000 \\
\text { More than } \\
30,000\end{array}$ & $\begin{array}{l}15 \\
27 \\
69 \\
53 \\
\\
60\end{array}$ & $\begin{array}{r}6.7 \\
12.1 \\
30.8 \\
23.7 \\
26.8\end{array}$ \\
\hline Education & $\begin{array}{l}\text { "PhD } \\
\text { Master's } \\
\text { degree } \\
\text { Bachelor's } \\
\text { degree } \\
\text { Diploma } \\
\text { level" } \\
\text { No } \\
\text { qualifications }\end{array}$ & $\begin{array}{c}9 \\
102 \\
107 \\
5 \\
1\end{array}$ & $\begin{array}{r}4.0 \\
45.5 \\
47.8 \\
2.2 \\
0.4\end{array}$ \\
\hline Repeat & $\begin{array}{l}\text { "No previous } \\
\text { visit } \\
1-2 \text { times } \\
\text { 3-4 times } \\
\text { More than } 4\end{array}$ & $\begin{array}{c}69 \\
102 \\
27 \\
26\end{array}$ & $\begin{array}{l}30.8 \\
45.5 \\
12.1 \\
11.6\end{array}$ \\
\hline
\end{tabular}

\subsection{Measures}

The research model consists of six factors including joy, love, positive surprise, overall image, satisfaction; and recommend behaviour. Measurement variable (shown in Appendix 2) considered for each construct were either selected or modified from previous studies.

Measuring emotional factors in this study was done mainly through the adapted Destination Emotion Scales ("DES") conceptual model of Hosany and Gilbert [8] which has been used recently in some research $[6,9,32]$. To measure the effect of tourists' emotional experiences to a destination, first, the emotion of Joy was measured by a five item scales (enthusiasm, delight, cheerful, pleasure, joy) from previous studies [6, 9]. Secondly, the emotion of Love was measured using five items (warm-hearted, affection, caring, love, and tenderness) based on [6,9], and emotion of Positive Surprise was measured by 5 items 
(amazement, astonishment, surprise, inspiration, fascinated), as proposed by [6, 9].

To measure the overall destination image, this study uses three (3) items with three (3) different couples of 7-point Likert scales such as "unfavourable-favourable", "dislike very much- like very much", and "strongly disagree - strongly agree". It was adopted from $[3,50,51]$.

Fourth, tourist satisfaction was measured through three items taken from $[8,50,52]$ with three couples of 7-point Likert scales included: "very satisfied -very dissatisfied", "much worse than expected - much better than expected", and "strongly disagree - strongly agree.

Behaviour of the intention of willingness to recommend was measured using three items based on $[44,53]$. The responders evaluate by using their confirmation by 7-point scales ranging from "strongly disagree" to "strongly agree". Additionally, the reliability of the testing question of behavior intention is used "Which tools will you use for your recommendation?" with three items "Have done already", "Will do", "Will not do".

Descriptive statistics of the questionnaire are provided in Appendix 1; all the variables values were ranged from minimum (1) to maximum (7). Emotion variables (joy, love positive surprise) were found as the favourable. Among the emotion variables, the respondents evaluated joy as the most favourable with a mean score of 5.51. Besides, the participants rate favourably for destination image with a mean score of 5.80. Satisfaction was also found respectively favourable with a mean score of 5.23. Finally, behavioural intention of willingness to recommend was positively favourable with mean a score of 4.12 .

\subsection{Tools for Analysis}

Statistical package for social science (SPSS 20.0) and analysis of moment structures (AMOS 21.0) software were used to conduct analysis, to achieve the purpose and test hypothesise of this research. Descriptive analysis and test of reliability of the measurement items, were done by SPSS 20.0. With AMOS 21.0, confirmatory factor analysis (CFA), following SEM to test the hypothesis.

\section{Results and Discussion}

\subsection{Testing of reliability and Validity of the measurement Model}

To measure the reliability of variables, Cronbach's alpha method is often used. According to Nunnally and Bernstein [54],the measurement standard of internal consistency reliability is Cronbach Alpha above 0.70 and Corrected itemtotal correlation above 0.30 . In this study, the result showed that Corrected item-total correlation value of the two variables "Joy2" and "Lov4" were below than the standard value. Therefore, these two items were eliminated. After deleting two items, all the items in the scale which shown in Appendix 2 were satisfied with Cronbach Alpha value ranging from 0.717 to 0.930 , above 0.700 and none of the Corrected item-total correlation above 0.30 . Therefore, the values obtained suggest that all left constructs were internally consistent and reliable.

According to Hair, Anderson [55], the factor loading should be greater than 0.70 . Therefore, all of standardized factor were significant ranging from 0.71 to 0.93 base on Appendix 2. Composite reliability $(\mathrm{CR})$ and the Average variance extracted (AVE) measure the amount of variance explained by given construct, should be higher than 0.700 and 0.50 , respectively. As results showed in Appendix 2, the $\mathrm{CR}$ values ranged from 0.78 to 0.93 and $\mathrm{AVE}$ ranged from 0.54 to 0.73 , all the results are surpassed the recommended levels of 0.70 and 0.50 [55].

Table 2. Measurement model fit indicators

\begin{tabular}{|c|c|c|c|c|}
\hline $\begin{array}{l}\mathbf{N} \\
\mathbf{0}\end{array}$ & Fit indices & $\begin{array}{c}\text { Criter } \\
\text { ia }\end{array}$ & $\begin{array}{c}\text { Indica } \\
\text { tors }\end{array}$ & $\begin{array}{c}\text { Refere } \\
\text { nce } \\
\text { source }\end{array}$ \\
\hline & "Chi-square & P & & \\
\hline 1 & (CMIN)" & $<0.05$ & 0.000 & \\
\hline & $\begin{array}{l}\text { "Chi- } \\
\text { square/Degree of } \\
\text { Freedom }\end{array}$ & & & \\
\hline 2 & $\begin{array}{l}\text { (CMIN/DF)" } \\
\text { "Root Mean }\end{array}$ & $<2-5$ & 1.353 & \\
\hline & Square Error of & & & \\
\hline 3 & (RMSEA)" & $<0.1$ & 0.04 & $\begin{array}{l}\text { [Tabac } \\
\text { hnick }\end{array}$ \\
\hline 4 & $\begin{array}{l}\text { (GFI)" } \\
\text { "Comnarative Fit }\end{array}$ & $>0.90$ & 0.904 & Fidell \\
\hline 5 & Index (CFI)" & $>0.95$ & 0.976 & 57 \\
\hline 6 & $\begin{array}{l}\text { "Tucker - Lewis } \\
\text { Index (TLI)" }\end{array}$ & $>0.90$ & 0.972 & $\begin{array}{l}\text { Steiger } \\
[58]]\end{array}$ \\
\hline & & & & \\
\hline
\end{tabular}

The recommended acceptance of considerable fit for a model requires that the obtained fit-indices 
of goodness-of-fit statistics (GFI), Tucker - Lewis Index (TLI) should be greater than 0.90 [58]. Comparative Fit Index (CFI) should be greater than 0.95, Root Mean Square Error of Approximation (RMSEA) should be less than 0.080 [56]. As results presented in Table 2, the CFA results compared with model fit indices, the measurement model of this study was satisfied and considered as a good fit of the model fit indices. P-value of all the indices were less than 0.05 . Chi-square $(0.000)$ less than 2 and RMSEA (0.035) less than 0.1. Other indices consist of GFI (0.909); CFI (0.982); and TLI (0.979) were higher than suggested goodness-of-fit values for proposed structure model (Bentler \& Bonett, 1980).

\subsection{Testing of the Structural Equation Model}

Structural Equation Model was Conducted by AMOS 21 using maximum likelihood parameter that evaluated the hypotheses of the model (Appendix 3). Table 3 illustrated the results of structural model. In total, eight out of nine hypotheses were supported. The positive relationship between emotion of joy and overall destination image $(\mathrm{H} 1: \beta 1=0.133, \mathrm{t}=2.046, \mathrm{p}<$ 0.05 ) indicated that $\mathrm{H} 1 \mathrm{was}$ supported. According to $\mathrm{H} 2$, the positive estimate of coefficients between emotion of love and overall image had significant positive effects $(\mathrm{H} 2: \beta 2=0.094, \mathrm{t}=2.172, \mathrm{p}<$ $0.05)$. Thus, $\mathrm{H} 2$ was supported. The emotion of Positive Surprise $(\mathrm{H} 3: \beta 3=0.224, \mathrm{t}=4.103, \mathrm{p}<$ 0.001 ) had significant positive effects on overall image, supporting H3. These results further support the studies by the research $[7,33]$ The emotion of Joy had significant positive effect on tourist satisfaction ( $\mathrm{H} 4: \beta 4=0.34, \mathrm{t}=3.224, \mathrm{p}<0.01)$, the emotion of love had significant positive on tourist satisfaction (H5: $\left.\beta 5=0.187^{* *}, \mathrm{t}=2.671, \mathrm{p}<0.01\right)$, indicated that H4, H5 was supported. While, the relationship between the emotion of Positive surprise and tourist satisfaction (H6: $\beta 6=-0.034, \mathrm{t}=$ $-0.376, p>0.05)$ was not supported. These results of this study contradicts the results of the paper by Sharma and Nayak [7], in which no significant association was found between positive surprise and satisfaction.

Overall image showed significant positive impact to tourist satisfaction $(\mathrm{H} 7: \beta 7=0.398, \mathrm{t}=$ $2.800, \mathrm{p}<0.01)$. Finally, overall image had significant positive influences on recommend the destination (H8: $\beta 8=0.612, \mathrm{t}=4.903, \mathrm{p}<0.01)$ and ttourist satisfaction had influence positively to recommend the destination $(\mathrm{H} 9: \beta 9=0.42, \mathrm{t}=$ $5.046, \mathrm{p}<0.01$ ), thus supporting H8, H9. Eid, El-
Kassrawy [41] also found a similar result in their respective research setting.

Table 3. Hypotheses results for structural model

\begin{tabular}{cccc}
\hline $\begin{array}{c}\text { Hyp } \\
\text { othes } \\
\text { is }\end{array}$ & $\begin{array}{c}\text { Path } \\
\text { Correlation }\end{array}$ & $\begin{array}{c}\text { Standar } \\
\text { dized } \\
\text { Path } \\
\text { Coefficie } \\
\text { nts }\end{array}$ & $\begin{array}{c}\text { t- } \\
\text { value }\end{array}$ \\
& & Results \\
& & & \\
\hline
\end{tabular}

H1 The emotion \begin{tabular}{l}
$\begin{array}{l}\text { of Joy } \rightarrow \\
\text { Overall image }\end{array}$ \\
\hline
\end{tabular}

H2 The emotion $\begin{aligned} & \text { of Love } \rightarrow \\ & \text { Overall image }\end{aligned}$
O.

\begin{tabular}{|c|c|c|c|c|}
\hline H3 & $\begin{array}{l}\text { The emotion } \\
\text { of Positive } \\
\text { Surprise } \rightarrow \\
\text { Overall image }\end{array}$ & $0.224 * * *$ & 4.103 & Supported \\
\hline
\end{tabular}

H4 The emotion Supported $\begin{array}{lll}\text { of Joy } \rightarrow & 0.34 * * & 3.224 \\ \text { tourist } \\ \text { satisfaction }\end{array}$

\begin{tabular}{|c|c|c|c|c|}
\hline H5 & $\begin{array}{l}\text { The emotion } \\
\text { of Love } \rightarrow \\
\text { tourist } \\
\text { satisfaction }\end{array}$ & $0.187^{* *}$ & 2.671 & Supported \\
\hline H6 & $\begin{array}{l}\text { The emotion } \\
\text { of Positive } \\
\text { surprise } \rightarrow \\
\text { satisfaction }\end{array}$ & -0.034 & $0 . \overline{376}$ & $\begin{array}{c}\text { Not } \\
\text { Supported }\end{array}$ \\
\hline $\mathrm{H} 7$ & $\begin{array}{l}\text { Overall image } \\
\rightarrow \text { tourist } \\
\text { satisfaction }\end{array}$ & $0.398^{* *}$ & 2.8 & Supported \\
\hline $\mathrm{H} 8$ & $\begin{array}{l}\text { Overall image } \\
\rightarrow \\
\text { Recommend } \\
\text { the destination }\end{array}$ & $0.612 * * *$ & 4.903 & Supported \\
\hline H9 & $\begin{array}{l}\text { Tourist } \\
\text { satisfaction } \rightarrow \\
\text { Recommend } \\
\text { the destination }\end{array}$ & $0.42 * * *$ & 5.046 & Supported \\
\hline
\end{tabular}

\section{Conclusions}

The findings from the survey data analysis provide the explanations for the research questions as 
follows:

First, Joy and Love have contributed to creating the antecedents in the relationship among overall image, satisfaction, and willingness to recommend. Joy and Love were emotional experiences of international tourists had with Vietnam image after experiencing it. Hence, those emotions contributed to satisfy international tourists and encouraged them to recommend Vietnam image to their friends.

Second, Positive Surprise had effected on Overall Image however it did not support the satisfaction of the tourists.

The results of this study provided consistent supported to prior studies of Prayag and Hosany and their collaborators that positive emotions impact on the overall image, satisfaction, and both effect intention to recommend $[8,33]$. The theoretical and conceptual modes of Destination Emotion Scales (DES) were tested and the study's evidence were appropriate for Vietnam context.

In prior studies, the surprise was considered as a key component of satisfaction [59]. In addition, the results of prior studies relevant to the relationship among emotional experiences, overall image and satisfaction are confirmation for these concepts [6, 7] regardless different contexts. However, the research results in Vietnam context opposites with the previous relationship results of variables such as emotional experiences, overall image, and satisfaction. Positive surprise did not support for the relationship of emotional experiences with satisfaction while joy and love were supported. In the tourism area, delight used to be considered as the highest level of tourists' satisfaction. According to Plutchik [10], there is a related relationship between delight and positive surprise. Based on this concept, it is said that the foreign tourists visiting Vietnam are not satisfied at the highest level. Nevertheless, this study did not examine the negative surprise to qualify of tourists' surprise emotion followed by respectively, positive and negative affective reactions. Furthermore, the study did not include the tourism service quality to measure the surprise emotion which suggested by some foreign tourists during the survey. Therefore, the findings of the study are interesting to suggest the further investigation of surprise emotion in Vietnam context among tourism service quality mediated by negative surprise.

In the literature review, positive surprise is often associated with joy to create the delighted feeling and contribute to satisfying the customers.
However, the study results pointed out the mixture of emotions (joy, love, and positive surprise) are different toward satisfaction mediated by different contexts. Thus, discerning emotions of joy and love impact tourist's satisfaction and willingness to recommend Vietnam as a tourist destination is necessary to improve the tourism marketing strategies.

The results of this study addressed the research objectives which are: 1) emotional experiences have significant effects on overall image, satisfaction, and both effect on willingness to recommend; 2) foreign tourists have many emotional levels of joy and love rather than positive surprise when they visit a destination; 3) joy, love directly impact the two variables satisfaction and overall image and since then, effect willingness to recommend.

The role of emotions in marketing was acknowledged through this study. The research conducted was on emotional components to tourist's experience. Among positive emotion, Joy and Love influenced significantly to tourist satisfaction while positive surprise did not impact. In conclusion, to increase international tourists' satisfaction, future implementations of tourism marketing strategies should focus on improving the emotion of joy and love. Tourism professionals should create a marketing campaign that takes into account the emotions elicited by the destinations. Tourist destination advertising should focus on stimulating and evoking certain emotions with the goal of activating and promoting good feelings. Destinations all across the world have used music, photography, and visual effects in their advertising campaigns to gain emotional responses from travelers.

The paper contains serval limitations which may be suitable for further study in the future.

First, the limitation of language, the different language and culture partly affects the quality of the survey in a different way [60]. English was used as the main language in conducting the survey. However, Asian participants accounted for $74.6 \%$. Most of them came from various countries where English is not their mother tough language such as Japan, Malaysia, Philippine, Myanmar, Cambodia, China, Taiwan, Thailand, India, etc. Moreover, the categorize emotions of DES model are similar in translation from English to other languages. Hence, future research should apply multi-languages in survey questionnaires and explanation of emotion definition for appropriate candidates. 
Second, the survey was undertaken by both methods which were online and offline. However, the usable data was collected by an online survey on foreign social network community pages. Thus, the participants were not diversified. For future study, offline methods should be used more widely.

Third, the study only focused on examining positive emotions omitting negative emotional factors. The findings of unsupported positive surprises and satisfaction derived from an imbalance in the emotion study model. Hence, further study should consider adding negative emotions for analysis, especially the emotion of negative surprise.

Finally, the paper relied on self-report utilizing recalled memories, the respondents were requested to recall their emotions about some places that they may have visited more than two years ago. Therefore, their memories of their emotions might reflect inaccurately when they answered the survey questions. Future research should also consider applying the qualitative method and conduct the surveys with interviews both from tourists and tourism providers.

\section{References:}

[1] 1. VNAT, Tourism Annual report in 2017. Vietnam National Administration of Tourism, 2017. 5-6.

[2] 2. Giang, P., Examining international tourists satisfaction with Hanoi tourism. Retreived from http://vietnamtourism. gov. vn/english/index. php/items/5847/2, 2013.

[3] 3. Hương, H.T.T. and N.V. Mạnh, Impact of Destination Image on the Loyalty of International Tourists to Hanoi. VNU Journal of Science: Economics and Business, 2015. 31(5E).

[4] 4. Hai, D.N., A study of Service quality and Intention to Visit for Hanoi tourist. 義守大學企業管理學系學位論文, 2015: p. 147.

[5] 5. Galí, N., R. Camprubí, and J.A. Donaire, Analysing tourism slogans in top tourism destinations. Journal of Destination Marketing \& Management, 2017. 6(3): p. 243-251.

[6] 6. Hosany, S. and G. Prayag, Patterns of tourists' emotional responses, satisfaction, and intention to recommend. Journal of Business Research, 2013. 66(6): p. 730-737.

[7] 7. Sharma, P. and J.K. Nayak, Testing the role of tourists' emotional experiences in predicting destination image, satisfaction, and behavioral intentions: A case of wellness tourism. Tourism Management Perspectives, 2018. 28: p. 41-52.
[8] 8. Hosany, S. and D. Gilbert, Measuring tourists' emotional experiences toward hedonic holiday destinations. Journal of travel research, 2010. 49(4): p. 513-526.

[9] 9. Hosany, S., et al., Measuring tourists' emotional experiences: Further validation of the destination emotion scale. Journal of Travel Research, 2015. 54(4): p. 482-495.

[10] 10. Plutchik, R., Emotion. A psychoevolutionary synthesis, 1980.

[11] 11. Whang, Y.-O., et al., Falling in love with a product: The structure of a romantic consumer-product relationship. ACR North American Advances, 2004.

[12] 12. Carroll, B.A. and A.C. Ahuvia, Some antecedents and outcomes of brand love. Marketing letters, 2006. 17(2): p. 79-89.

[13] 13. Wu, M.-Y., "I would love to work in tourism, but...": Exploring the outcomes of an ethnic tourism education initiative. Journal of Hospitality, Leisure, Sport \& Tourism Education, 2013. 12(1): p. 47-58.

[14] 14. Swanson, K., Destination brand love: managerial implications and applications to tourism businesses. Journal of Place Management and Development, 2017.

[15] 15. Andriotis, K., P. Foroudi, and R. Marvi, Heritage destination love. Qualitative Market Research: An International Journal, 2020.

[16] 16. Thomas, M., Ryanair: success before love. Strategic Direction, 2015.

[17] 17. Izard, C.E., Theories of emotion and emotion-behavior relationships, in Human emotions. 1977, Springer. p. 19-42.

[18] 18. Lindgreen, A. and J. Vanhamme, To surprise or not to surprise your customers: The use of surprise as a marketing tool. Journal of Customer Behaviour, 2003. 2(2): p. 219-242.

[19] 19. Hutter, K. and S. Hoffmann, Surprise, surprise. Ambient media as promotion tool for retailers. Journal of Retailing, 2014. 90(1): p. 93-110.

[20] 20. Prayag, G., S. Hosany, and K. Odeh, The role of tourists' emotional experiences and satisfaction in understanding behavioral intentions. Journal of Destination Marketing \& Management, 2013. 2(2): p. 118127.

[21] 21. Lerner, J.S. and D. Keltner, Fear, anger, and risk. Journal of personality and social psychology, 2001. 81(1): p. 146.

[22] 22. Ene, D. and P. Schofield, An integrated approach to consumer decision making for budget city breaks: The role of 
emotion. International Journal of Tourism Research, 2011. 13(4): p. 368-383.

[23] 23. Dubé, L. and K. Menon, Multiple roles of consumption emotions in post-purchase satisfaction with extended service transactions. International Journal of Service Industry Management, 2000.

[24] 24. Walsh, G., et al., Emotions, storeenvironmental cues, store-choice criteria, and marketing outcomes. Journal of Business Research, 2011. 64(7): p. 737-744.

[25] 25. Han, H. and C. Jeong, Multidimensions of patrons' emotional experiences in upscale restaurants and their role in loyalty formation: Emotion scale improvement. International Journal of Hospitality Management, 2013. 32: p. 59-70.

[26] 26. Kumar, V. and J. Nayak, Examining the relationship between patterns of emotional responses, satisfaction, and loyalty. An International Journal of Tourism and Hospitality Research, 2015.

[27] 27. Eusébio, C. and A.L. Vieira, Destination attributes' evaluation, satisfaction and behavioural intentions: A structural modelling approach. International Journal of Tourism Research, 2013. 15(1): p. 66-80.

[28] 28. Susanti, C.E., The Effect of Push Motivational Factors and Pull Motivational Factors on Tourist Loyalty Through Satisfaction on Halal Tourists in East Java. WSEAS Transactions on Environment and Development, 2021. 17: p. 510-519.

[29] 29. Stylidis, D., K.M. Woosnam, and M. Ivkov, Tourists' emotional solidarity with residents: a segmentation analysis and its links to destination image and loyalty. Journal of Destination Marketing \& Management, 2020. 17: p. 100458 .

[30] 30. Sharma, P. and J.K. Nayak, Do tourists' emotional experiences influence images and intentions in yoga tourism? Tourism Review, 2019.

[31] 31. Afshardoost, M. and M.S. Eshaghi, Destination image and tourist behavioural intentions: A meta-analysis. Tourism Management, 2020. 81: p. 104154.

[32] 32. Hosany, S., et al., Mediating effects of place attachment and satisfaction on the relationship between tourists' emotions and intention to recommend. Journal of Travel Research, 2017. 56(8): p. 1079-1093.

[33] 33. Prayag, G., et al., Understanding the relationships between tourists' emotional experiences, perceived overall image, satisfaction, and intention to recommend. Journal of travel research, 2017. 56(1): p. 41-54.

[34] 34. Farber, M.E. and T.E. Hall, Emotion and environment: Visitors' extraordinary experiences along the Dalton Highway in Alaska. Journal of Leisure Research, 2007. 39(2): p. 248-270.

[35] 35. Walmsley, D.J. and M. Young, Evaluative images and tourism: The use of personal constructs to describe the structure of destination images. Journal of travel research, 1998. 36(3): p. 65-69.

[36] 36. Chen, H.-B., S.-S. Yeh, and T.-C. Huan, Nostalgic emotion, experiential value, brand image, and consumption intentions of customers of nostalgic-themed restaurants. Journal of Business Research, 2014. 67(3): p. 354-360.

[37] 37. Faullant, R., K. Matzler, and T.A. Mooradian, Personality, basic emotions, and satisfaction: Primary emotions in the mountaineering experience. Tourism Management, 2011. 32(6): p. 1423-1430.

[38] 38. Grappi, S. and F. Montanari, The role of social identification and hedonism in affecting tourist re-patronizing behaviours: The case of an Italian festival. Tourism management, 2011. 32(5): p. 1128-1140.

[39] 39. Chen, C.-F. and D. Tsai, How destination image and evaluative factors affect behavioral intentions? Tourism management, 2007. 28(4): p. 1115-1122.

[40] 40. Lee, S.W. and K. Xue, A model of destination loyalty: Integrating destination image and sustainable tourism. Asia Pacific Journal of Tourism Research, 2020. 25(4): p. 393-408.

[41] 41. Eid, R., Y.A. El-Kassrawy, and G. Agag, Integrating destination attributes, political (in) stability, destination image, tourist satisfaction, and intention to recommend: $A$ study of UAE. Journal of Hospitality \& Tourism Research, 2019. 43(6): p. 839-866.

[42] 42. Williams, D.R. and J.J. Vaske, The measurement of place attachment: Validity and generalizability of a psychometric approach. Forest science, 2003. 49(6): p. 830-840.

[43] 43. Meng, F., Y. Tepanon, and M. Uysal, Measuring tourist satisfaction by attribute and motivation: The case of a naturebased resort. Journal of vacation marketing, 2008. 14(1): p. 41-56.

[44] 44. Wang, T.-L., P.T.K. Tran, and V.T. Tran, Destination perceived quality, tourist 
satisfaction and word-of-mouth. Tourism Review, 2017.

[45] 45. Huang, S., B. Weiler, and G. Assaker, Effects of interpretive guiding outcomes on tourist satisfaction and behavioral intention. Journal of Travel Research, 2015. 54(3): p. 344-358.

[46] 46. Pai, C.-K., et al., The role of perceived smart tourism technology experience for tourist satisfaction, happiness and revisit intention. Sustainability, 2020. 12(16): p. 6592.

[47] 47. Ozturk, U.A. and H. Gogtas, Destination attributes, satisfaction, and the cruise visitor's intent to revisit and recommend. Tourism Geographies, 2016. 18(2): p. 194-212.

[48] 48. Shafiee, M.M., R.A. Tabaeeian, and $\mathrm{H}$. Tavakoli. The effect of destination image on tourist satisfaction, intention to revisit and WOM: An empirical research in Foursquare social media. in 2016 10th International Conference on e-Commerce in Developing Countries: with focus on e-Tourism (ECDC). 2016. IEEE.

[49] 49. Hair, J.F., et al., Multivariate data analysis. Englewood Cliff. New jersey, USA, 1998. 5(3): p. 207-2019.

[50] 50. Assaker, G. and R. Hallak, Moderating effects of tourists' novelty-seeking tendencies on destination image, visitor satisfaction, and short-and long-term revisit intentions. Journal of Travel Research, 2013. 52(5): p. 600-613.

[51] 51. Beerli, A. and J.D. Martin, Factors influencing destination image. Annals of tourism research, 2004. 31(3): p. 657-681.

[52] 52. Chen, Y., H. Zhang, and L. Qiu, A review on tourist satisfaction of tourism destinations, in LISS 2012. 2013, Springer. p. 593-604.

[53] 53. Artuğer, S., B.C. Çetinsöz, and İ. Kilıç, The effect of destination image on destination loyalty: An application in Alanya. European Journal of Business and Management, 2013. 5(13): p. 124-136.

[54] 54. Nunnally, J.C. and I.H. Bernstein, Psychometric theory. 1994.

[55] 55. Hair, J., et al., Conjoint analysis, Multivariate data analysis. 1998, New Jersey: Prentice Hall.

[56] 56. Tabachnick, B., L. Fidell, and S. Osterlind, Using multivariate statistics. Allyn \& 1205 Bacon. 2001, Pearson Education.

[57] 57. Bentler, P.M. and D.G. Bonett, Significance tests and goodness of fit in the analysis of covariance structures. Psychological bulletin, 1980. 88(3): p. 588.

[58] 58. Steiger, J.H., Understanding the limitations of global fit assessment in structural equation modeling. Personality and Individual differences, 2007. 42(5): p. 893-898.

[59] 59. Westbrook, R.A. and R.L. Oliver, The dimensionality of consumption emotion patterns and consumer satisfaction. Journal of consumer research, 1991. 18(1): p. 84-91.

[60] 60. Russell, J.A., Culture and the categorization of emotions. Psychological bulletin, 1991. 110(3): p. 426.

\section{[61] Declaration of Conflicting Interests}

[62] The authors declared no potential conflicts of interest with respect to the research, and or publication of this article.

\section{Sources of Funding for Research}

Presented in a Scientific Article or

\section{Scientific Article Itself}

This research is funded by International

School, Vietnam National University, Hanoi (VNU-IS) under project number KHCN_2020.01

\section{Creative Commons Attribution License 4.0 (Attribution 4.0 International, CC BY 4.0)}

This article is published under the terms of the Creative Commons Attribution License 4.0 https://creativecommons.org/licenses/by/4.0/de ed.en US 


\section{APPENDIX}

Appendix 1. Descriptive statistics of the questionnaire items

\begin{tabular}{|c|c|c|c|}
\hline Observed Variable & Code & Mean & Std. Deviation \\
\hline Joy & & 5.51 & 0.978 \\
\hline "I feel Cheerful toward that destination(s)" & Joyl & 5.92 & 1.131 \\
\hline "I feel a sense of Delight toward that destination(s)" & Joy2 & 4.32 & 2.060 \\
\hline "I feel a sense of Enthusiasm toward that destination(s)" & Joy3 & 5.75 & 1.275 \\
\hline "I feel a sense of Joy toward that destination(s)" & Joy4 & 5.76 & 1.233 \\
\hline "I feel a sense of Pleasure toward that destination(s)" & Joy5 & 5.79 & 1.233 \\
\hline Love & & 3.22 & 1.167 \\
\hline "I feel a sense of Affection toward that destination(s)" & Lov1 & 2.94 & 1.535 \\
\hline "I feel a sense of Caring toward that destination(s)" & Lov2 & 3.06 & 1.638 \\
\hline "I feel a sense of Love toward that destination(s)" & Lov3 & 3.17 & 1.575 \\
\hline "I feel a sense of Tenderness toward that destination(s)" & Lov4 & 3.87 & 1.961 \\
\hline "I feel Warm-hearted toward that destination(s)" & Lov5 & 3.05 & 1.598 \\
\hline Positive surprise & & 5.49 & 1.220 \\
\hline "I feel a sense of Amazement toward that destination(s)" & Sur1 & 5.56 & 1.348 \\
\hline "I feel a sense of Astonishment toward that destination(s)" & Sur2 & 5.52 & 1.362 \\
\hline "I feel Fascinated about that destination(s)" & Sur3 & 5.41 & 1.386 \\
\hline "I feel a sense of Inspiration toward that destination(s)" & Sur4 & 5.51 & 1.382 \\
\hline "I feel a sense of Surprise toward that destination(s)" & Sur5 & 5.45 & 1.416 \\
\hline Destination image & & 5.80 & 0.818 \\
\hline $\begin{array}{l}\text { "How would you describe the overall image that you have of that } \\
\text { destination(s) before the experience"? }\end{array}$ & & 5.92 & 0.857 \\
\hline $\begin{array}{l}\text { "How would you describe your overall feeling about that } \\
\text { destination(s)?" }\end{array}$ & Ima2 & 5.72 & 0.996 \\
\hline $\begin{array}{l}\text { "The image that I have of that destination(s) is as good or even } \\
\text { better than other similar destinations in other countries" }\end{array}$ & Ima3 & 5.76 & 1.085 \\
\hline Satisfaction & & 5.23 & 1.295 \\
\hline $\begin{array}{l}\text { "How would you describe your overall satisfaction with your stay } \\
\text { in that destination(s)?" }\end{array}$ & Sat1 & 3.81 & 1.510 \\
\hline $\begin{array}{l}\text { "Overall, compared to your expectations, how would you rate your } \\
\text { experience with the destination(s)" }\end{array}$ & Sat2 & 4.06 & 1.598 \\
\hline "My visit to that destination(s) is worth my time and effort" & Sat3 & 4.48 & 1.562 \\
\hline Willingness to recommend & & 4.12 & 1.292 \\
\hline "I will recommend that destination(s) to other people" & Rec1 & 5.05 & 1.520 \\
\hline "I will say positive things about that destination(s) to other people" & $\operatorname{Rec} 2$ & 5.16 & 1.486 \\
\hline "I will encourage friends and relatives to visit that destination(s)" & Rec3 & 5.49 & 1.274 \\
\hline
\end{tabular}

Appendix 2. Reliability and validity of the constructs

\begin{tabular}{|c|c|c|c|c|c|c|}
\hline Observed Variable & Coding & $\begin{array}{c}\text { Cronbach } \\
" \alpha "\end{array}$ & $\begin{array}{c}\text { Corrected } \\
\text { Item }\end{array}$ & $\begin{array}{c}\text { Standard } \\
\text { factor } \\
\text { loadings }\end{array}$ & $\begin{array}{c}\text { Composite } \\
\text { reliability }\end{array}$ & AVE \\
\hline
\end{tabular}




\begin{tabular}{|c|c|c|c|c|c|c|}
\hline Observed Variable & Coding & $\begin{array}{l}\text { Cronbach } \\
\text { " } \alpha "\end{array}$ & $\begin{array}{l}\text { Corrected } \\
\text { Item }\end{array}$ & $\begin{array}{c}\text { Standard } \\
\text { factor } \\
\text { loadings }\end{array}$ & $\begin{array}{l}\text { Composite } \\
\text { reliability }\end{array}$ & AVE \\
\hline Joy & & \multicolumn{3}{|l|}{0.887} & 0.89 & 0.67 \\
\hline $\begin{array}{l}\text { "I feel Cheerful toward that } \\
\text { destination(s)" }\end{array}$ & Joy1 & & 0.764 & 0.88 & & \\
\hline $\begin{array}{l}\text { "I feel a sense of Enthusiasm } \\
\text { toward that destination(s)" }\end{array}$ & Joy3 & & 0.774 & 0.82 & & \\
\hline $\begin{array}{l}\text { "I feel a sense of Joy toward } \\
\text { that destination(s)" }\end{array}$ & Joy4 & & 0.747 & 0.73 & & \\
\hline $\begin{array}{l}\text { "I feel a sense of Pleasure } \\
\text { toward that destination(s)" }\end{array}$ & Joy5 & & 0.734 & 0.79 & & \\
\hline Love & & 0.888 & & & 0.89 & 0.67 \\
\hline $\begin{array}{l}\text { "I feel a sense of Affection } \\
\text { toward that destination(s)" }\end{array}$ & Lov1 & & 0.753 & 0.84 & & \\
\hline $\begin{array}{l}\text { "I feel a sense of Caring } \\
\text { toward that destination(s)" }\end{array}$ & Lov2 & & 0.797 & 0.87 & & \\
\hline $\begin{array}{l}\text { "I feel a sense of Love toward } \\
\text { that destination(s)" }\end{array}$ & Lov3 & & 0.732 & 0.75 & & \\
\hline $\begin{array}{l}\text { "I feel Warm-hearted toward } \\
\text { that destination(s)" }\end{array}$ & Lov5 & & 0.735 & 0.81 & & \\
\hline Positive surprise & & 0.930 & & & 0.93 & 0.73 \\
\hline $\begin{array}{l}\text { "I feel a sense of Amazement } \\
\text { toward that destination(s)" }\end{array}$ & Sur1 & & 0.782 & 0.84 & & \\
\hline $\begin{array}{l}\text { "I feel a sense of Astonishment } \\
\text { toward that destination(s)" }\end{array}$ & Sur2 & & 0.770 & 0.77 & & \\
\hline $\begin{array}{l}\text { "I feel Fascinated about that } \\
\text { destination(s)" }\end{array}$ & Sur3 & & 0.825 & 0.87 & & \\
\hline $\begin{array}{l}\text { "I feel a sense of Inspiration } \\
\text { toward that destination(s)" }\end{array}$ & Sur4 & & 0.865 & 0.89 & & \\
\hline $\begin{array}{l}\text { "I feel a sense of Surprise } \\
\text { toward that destination(s)" }\end{array}$ & Sur5 & & 0.838 & 0.88 & & \\
\hline Destination image & & 0.777 & & & 0.79 & 0.57 \\
\hline $\begin{array}{l}\text { "How would you describe the } \\
\text { overall image that you have of } \\
\text { that destination(s) before the } \\
\text { experience"? }\end{array}$ & Ima1 & & 0.692 & 0.70 & & \\
\hline $\begin{array}{l}\text { "How would you describe your } \\
\text { overall feeling about that } \\
\text { destination(s)?" }\end{array}$ & Ima2 & & 0.617 & 0.91 & & \\
\hline $\begin{array}{l}\text { "The image that I have of that } \\
\text { destination(s) is as good or } \\
\text { even better than other similar } \\
\text { destinations in other countries" }\end{array}$ & Ima3 & & 0.788 & 0.58 & & \\
\hline Satisfaction & & 0.774 & & & 0.78 & 0.54 \\
\hline $\begin{array}{l}\text { "How would you describe your } \\
\text { overall satisfaction with your } \\
\text { stay in that destination(s)?" }\end{array}$ & Sat1 & & 0.742 & 0.71 & & \\
\hline $\begin{array}{l}\text { "Overall, compared to your } \\
\text { expectations, how would you } \\
\text { rate your experience with the } \\
\text { destination(s)" }\end{array}$ & Sat2 & & 0.618 & 0.87 & & \\
\hline $\begin{array}{l}\text { "My visit to that destination(s) } \\
\text { is worth my time and effort" }\end{array}$ & Sat3 & & 0.715 & 0.64 & & \\
\hline
\end{tabular}




\begin{tabular}{|c|c|c|c|c|c|c|}
\hline Observed Variable & Coding & $\begin{array}{c}\text { Cronbach } \\
\text { " } \alpha "\end{array}$ & $\begin{array}{l}\text { Corrected } \\
\text { Item }\end{array}$ & $\begin{array}{l}\text { Standard } \\
\text { factor } \\
\text { loadings }\end{array}$ & $\begin{array}{l}\text { Composite } \\
\text { reliability }\end{array}$ & AVE \\
\hline Willingness to recommend & & \multicolumn{3}{|l|}{0.890} & 0.89 & 0.73 \\
\hline $\begin{array}{l}\text { "I will recommend that } \\
\text { destination(s) to other people" }\end{array}$ & Rec1 & & 0.819 & 0.93 & & \\
\hline $\begin{array}{l}\text { "I will say positive things } \\
\text { about that destination(s) to } \\
\text { other people" }\end{array}$ & $\operatorname{Rec} 2$ & & 0.851 & 0.83 & & \\
\hline $\begin{array}{l}\text { "I will encourage friends and } \\
\text { relatives to visit that } \\
\text { destination(s)" }\end{array}$ & Rec3 & & 0.855 & 0.79 & & \\
\hline
\end{tabular}

Appendix 3. The results of the research model

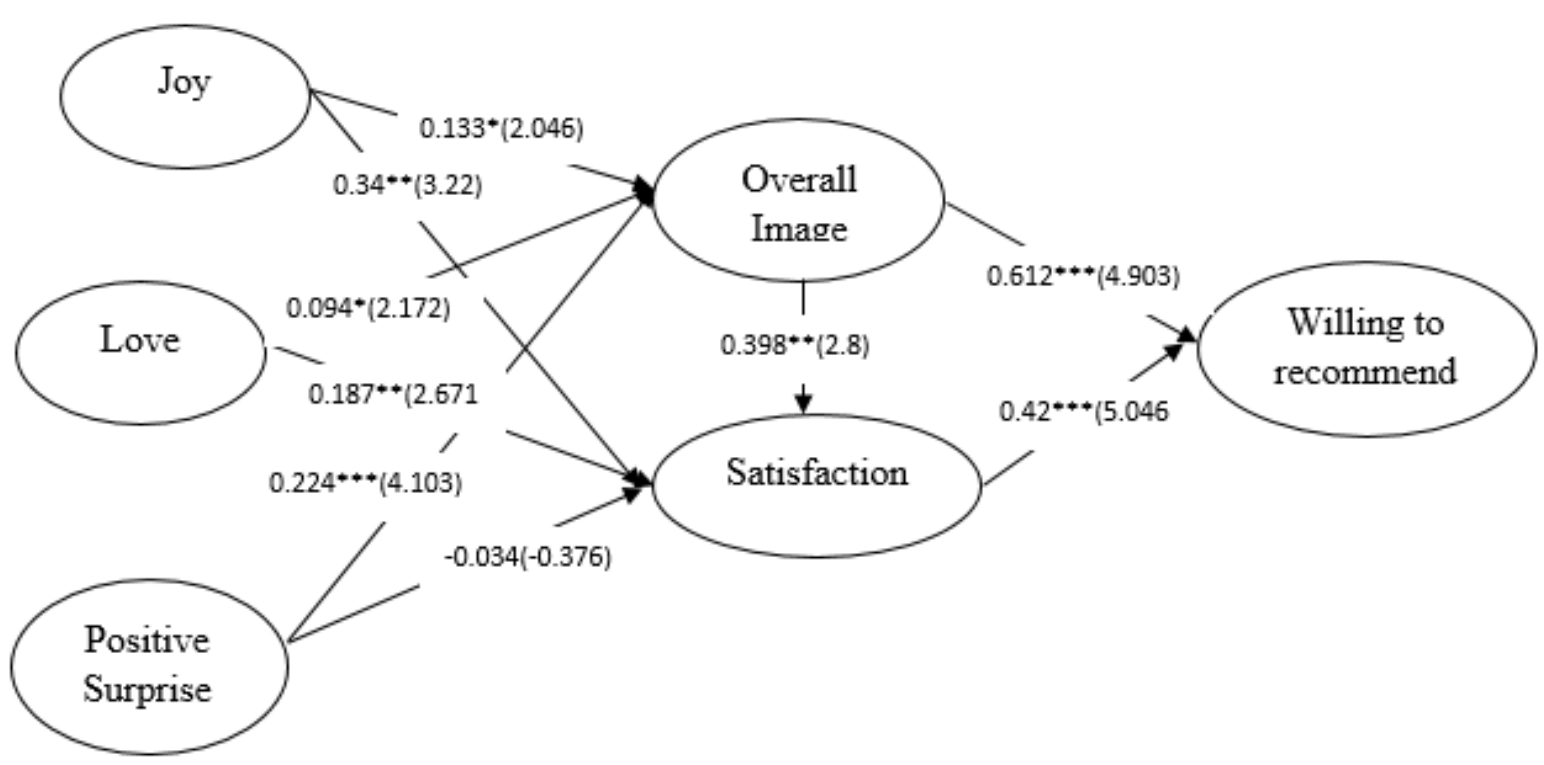

Note: ${ }^{*} \mathrm{p}<0.05 ;{ }^{* *} \mathrm{p}<0.01,{ }^{* * *} \mathrm{p}<0.001$ 